UDC 541.18.02;546.57

\author{
M.I. Skiba ${ }^{a}$, V.I. Vorobyova ${ }^{b}$, O.A. Pivovarov ${ }^{a}$, K.O. Sorochkina ${ }^{a}$, A.S. Shakun ${ }^{b}$
}

\title{
PLASMA-CHEMICAL-ASSISTED SYNTHESIS OF SILVER NANOPARTICLES USING GRAPE POMACE WASTE
}

\author{
a Ukrainian State University of Chemical Technology, Dnipro, Ukraine \\ b National Technical University of Ukraine «Igor Sikorsky Kyiv Polytechnic Institute», Kyiv, Ukraine
}

\begin{abstract}
Dispersions of silver nanoparticles (AgNPs) were prepared by two methods: a chemical reduction using plasma-chemically obtained water extract of grape pomace as a reducing and stabilizing agent and one-pot plasma-chemical-assisted synthesis using a grape pomace in an aqueous medium. The UV-vis spectrum of AgNPs exhibited a surface plasmon absorption at about $405-420 \mathrm{~nm}$, which originated from the formation of AgNPs. The UV-visible absorption spectral characteristics of silver nanoparticles prepared under different $\mathrm{Ag}^{+}$concentrations and durations of synthesis were studied. The results demonstrated that the synthesis via both methods provides the formation of AgNPs at the investigated concentrations of $\mathrm{Ag}^{+}(0.25-6.0 \mathrm{mmol} / \mathrm{L})$ during 5-10 min. Dynamic light scattering and scanning electron microscopy were employed to measure the hydrodynamic size and morphology of silver nanoparticles in suspensions. The prepared AgNPs were spherical with an average particle size of about $20-33 \mathrm{~nm}$. The results of powder X-ray diffraction method revealed that Ag nanoparticles had a face-centered cubic crystal structure. The catalytic performance of the AgNPs were ascertained in the reduction of 4-nitrophenol to 4-aminophenol in the presence of sodium borohydride.
\end{abstract}

Keywords: silver nanoparticle; low-temperature nonequilibrium plasma; grape pomace; catalytic degradation; nitrophenol.

DOI: $10.32434 / 0321-4095-2020-128-1-53-60$

\section{Introduction}

Metal nanoparticles (NPs), especially silver nanoparticles (AgNPs), have attracted a great attention both in the area of scientific researches and in industrial applications due to their excellent properties. The synthesis of AgNPs is generally carried out by various physical or chemical methods, such as reduction in solutions, thermal decomposition of silver compounds, microwave-assisted and photochemical reactions in the reverse micelles, etc. [1]. Despite on success of these methodologies, they have many limitations, including expensive chemical reagents and potential hazardous impact on the environment. These detrimental effects can be minimized by using an environmentally friendly facile approach.

Green nanotechnology integrates the principles of green chemistry and green engineering to produce eco-friendly safe nanoparticles that do not use toxic chemicals during a synthesis protocol [2]. Green synthesis uses environmentally compatible materials, such as bacteria, fungi and plants to synthesize the nanoparticles. However, the usage of plant extracts is more advantageous due to preventing risks and complications in the maintenance of cell cultures, when the reaction time decreases from days to hours. Various plants wastes have been utilized for the synthesis of AgNPs [1,2].

Grape is one of the world's largest fruit crop with a global production of 68 million tons [3], only about 38 million tons of which are further processed. Annually, around 2.5 million tons of grape pomace is generated. Grape pomace (GP) mainly consists of peels (skins), seeds and stems that correspond to $20-25 \%$ of the grape weight crushed to produce wine. In recent years, the management of food waste processing has emerged as a major concern. One of the food waste, grape pomace, as a great source of bioactive compounds, might be used for more environmentally-friendly processes in the synthesis of nanomaterials. However, an analysis of the pertinent literature revealed actual issues and 
shortcomings that limit the advancement of the green synthesis [1-4]. Major issues are associated with the source/type and concentration of the plant extracts and waste materials. The formation of NPs by using plant extracts proceeds, as a rule, in two stages: preparation of the extract and its subsequent use as a reducing/stabilizing agent. Maceration of solid material with different solvents is the most common method to prepare extracts [5]. These techniques often involve several extraction steps, thus take a lot of time. Different extraction techniques have been studied in an effort to increase the yield, including e.g. ultrasound-assisted extraction from grape stems, superheated liquid extraction from vine shoots and fluidized-bed extraction from grape canes [6].

Some scientists used additional influences on the reaction mixtures directly at the stage of the NPs formation and/or extract preparation. As an example, a variety of radiation sources emitting in the gamma, UV, vis or microwave ranges are used to synthesize AgNPs in the presence of plants extracts $[7,8]$. Among these, plasma-chemical treatment exhibits low instrumental requirements and allows simultaneously treating various samples in a short time [9].

Among plasma-chemical discharges, the contact nonequilibrium low-temperature plasma is a promising option from the point of view of practical application. Plasma discharge is generated between the electrode in a gaseous phase and a liquid surface, where another electrode is located [10]. Therefore, chemical transformations on the phase boundary are determined by the combined effect of the electrochemical oxidation-reduction, initiated photolysis reactions, the UV radiation and a flow of charged particles from the gaseous phase to the surface of the liquid medium. These factors may increase the extraction efficiency and concentration of the resulted extracts, and, as a consequence, the efficiency of a further synthesis of AgNPs.

The main goal of this work was to determine the synthesis conditions and catalytic properties of silver nanoparticles prepared via green methods using the grape pomace extract and the plasma-chemical treatment at the stages of extract preparation and directly for the NPs formation.

\section{Material and methods}

Green synthesis of silver nanoparticles with the use of plasma-chemical treatment at the different stages was performed by two following methods.

According to the first method, grape pomace, stored in plastic bags at $4^{\circ} \mathrm{C}$ before treatment, was dried at $100^{\circ} \mathrm{C}$ for $48 \mathrm{~h}$ and grounded to obtain a fine powder. The bidistilled water $(40 \mathrm{~mL})$ was added to $1 \mathrm{~g}$ of dry GP powder and thoroughly stirred. The resulting mixture was placed in a plasma-chemical reactor. The scheme and the operating principle of the industrial plasma-chemical reactors were given elsewhere [10,11].

The mixture was treated by contact nonequilibrium low-temperature plasma for $5 \mathrm{~min}$ (at the amperage of $\mathrm{I}=120 \mathrm{~mA}$ and the pressure of $\mathrm{P}=0.8 \mathrm{MPa}$ ), cooled and filtered. The freshly obtained GP water extract was used immediately after filtration. These extracts will be mentioned below as the plasma-chemically obtained grape pomace water extracts ( $\mathrm{PC} \mathrm{GPWE}$ ). $\mathrm{AgNO}_{3}$ solutions was used as $\mathrm{As} \mathrm{Ag}^{+}$-ions source $\left(\mathrm{C}_{\mathrm{Ag}}=0.025-\right.$ $6.0 \mathrm{mmol} / \mathrm{L}$ ). In a typical reaction procedure, $40 \mathrm{~mL}$ of GP extract was added to $40 \mathrm{~mL}$ of $\mathrm{AgNO}_{3}$ solution under stirring during $0.1 \mathrm{~min}$. The obtained mixture was heated to $75^{\circ} \mathrm{C}$ for an appropriate time. The change of color to the brown for $\mathrm{AgNO}_{3}-\mathrm{PC} \mathrm{GPWE}$ mixture indicated the formation of AgNPs. This method will be mentioned below as chemical synthesis using plasma-chemically obtained grape pomace water extract (the method I).

In accordance to the second method, $40 \mathrm{~mL}$ of $\mathrm{AgNO}_{3}$ aqueous solution with the concentration of $0.25-6.0 \mathrm{mmol} / \mathrm{L}$ was added to $1 \mathrm{~g}$ of dry GP powder under stirring. The resulting mixture was treated by contact nonequilibrium low-temperature plasma for 5 minutes (at the amperage of $\mathrm{I}=120 \mathrm{~mA}$ and the pressure of $\mathrm{P}=0.8 \mathrm{MPa}$ ), cooled and filtered. This method will be mentioned below as the plasmachemical-assisted synthesis using grape pomace in the aqueous medium (the method II).

The final product was a colloidal dispersion of silver nanoparticles in both methods. AgNPs obtained by chemical synthesis were centrifuged at $5000 \mathrm{rpm}$ for $5 \mathrm{~min}$. The dried powders were used for further characterization.

The spectra of colloidal solutions were recorded using a spectrophotometer UV-5800PC (FRU, China) equipped with quartz cuvettes in the wavelength range of $200-700 \mathrm{~nm}$.

The particle size distribution, polydispersity index and zeta potential of the prepared AgNPs colloids were determined by the dynamic light scattering technique using an analyzer Zetasizer Nano-25 (Malvern Instruments Ltd., Malvern, England) within the range of $0.1-10000 \mathrm{~nm}$. For the hydrodynamic diameter measurement, $1 \mathrm{~mL}$ of the sample was transferred into a disposable plastic cuvette and automatically equilibrated in the instrument for $2 \mathrm{~min}$. The data were recorded in triplicate. Microphotographs of nanoparticles were obtained by means of a scanning electron microscope 
JEOL JSM-6510LV (JEOL, Tokyo, Japan).

To test the catalytic activity of AgNPs, the reduction of 4-nitrophenol (4-NP) was monitored as follows: $1.5 \mathrm{~mL}$ of $4-\mathrm{NP}$ solution $(0.15 \mathrm{mM})$ was mixed with $1.0 \mathrm{~mL}$ of $\mathrm{NaBH}_{4}$ solution $(0.02 \mathrm{M})$ in a cell for UV-Vis measurements. The color immediately changed from light yellow to deep yellow; then, $0.5 \mathrm{~mL}$ of AgNPs solution was added to the above mixture. The intensity of the absorption peak at $400 \mathrm{~nm}$ was used to monitor the process of conversion from 4-nitrophenol to p-aminophenol.

\section{Results and discussion}

The most common technique used to elucidate and confirm the formation of silver nanoparticles is UV-Vis spectroscopy. Generally, metal nanoparticles, due to their nano dimension, exhibit surface plasmon resonance phenomenon, where the metal electrons in the conduction band oscillate collectively in the resonance at a certain wavelength of incident light. Colloidal silver nanoparticles demonstrate the absorption peak in the wavelength range from 380 to $450 \mathrm{~nm}$, depending on the complex dielectric constant of the metal, the cluster size and an environment [12]. Obviously, the concentration of silver nitrate plays an important role in the formation of the silver particles [13]. In order to illustrate the effect of silver nitrate concentration, different concentrations of $\mathrm{AgNO}_{3}$ were used to synthesize silver nanoparticles.

Figure 1 presents the UV-Vis absorption spectra of $\mathrm{AgNPs}$ prepared by two methods described above at different concentrations of $\mathrm{AgNO}_{3}$ (0.25$6.0 \mathrm{mmol} / \mathrm{L}$ ). The pure extract shows a maximum absorbance at $\lambda<300 \mathrm{~nm}$, which may be due to the functional compound extracted from GP. The presence of absorption peak in the range of 405$420 \mathrm{~nm}$ in the presented curves indicates the AgNPs formation after reaction with plasma-chemically

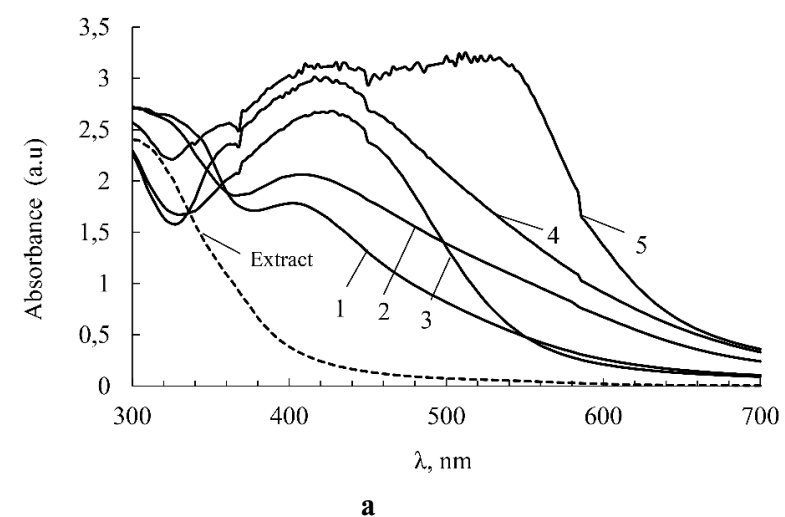

obtained GPWE (Fig. 1,a).

As can be seen in Fig. 1, the growth of silver nitrate concentrations from 0.25 to $6.0 \mathrm{mmol} / \mathrm{L}$ leads to an increase in the intensity of absorbance peak. Increasing intensity suggests that more nanoparticles are formed. However, while the concentration of silver nitrate changes from 1.0 to $3.0 \mathrm{mmol} / \mathrm{L}$, the intensity of absorbance peaks changed only slightly. This may be explained by the exhaustion of the reducing agent. With an increase in $\mathrm{Ag}^{+}$concentration up to $6.0 \mathrm{mmol} / \mathrm{L}$, the peaks intensity slightly increases and a pair of absorption peaks at $424 \mathrm{~nm}$ and $550 \mathrm{~nm}$ is formed. This indicates that aggregation occurs in this reactive system and the nanoparticles are well dispersed.

The plasma-chemical-assisted synthesis with grape pomace in the aqueous medium under the second method also leads to the formation of silver nanoparticles (Fig. 1,b). The absorption spectra of colloidal solutions showed a highly symmetric single absorption band with a maximum at $422 \mathrm{~nm}$ and a steadily increasing of intensity as a function of reaction time without any shift in intensity. This indicates a narrow and uniform size distribution of the synthesized AgNPs with the spherical shape, which is confirmed by relatively low polydispersity indexes.

The dependences of the absorbance (at $\lambda_{\max }$ ) in the recorded UV-Vis absorption spectra of AgNPs synthesized on the treatment duration are shown in Fig. 2.

It was established that a gradual increase in the absorbance is observed for both synthesis methods and different $\mathrm{AgNO}_{3}$ concentrations during first 510 min of the synthesis, which indicates the growth of AgNPs content with increasing treatment duration. However, plasma-chemical-assisted synthesis is more effective than the chemical synthesis and the time

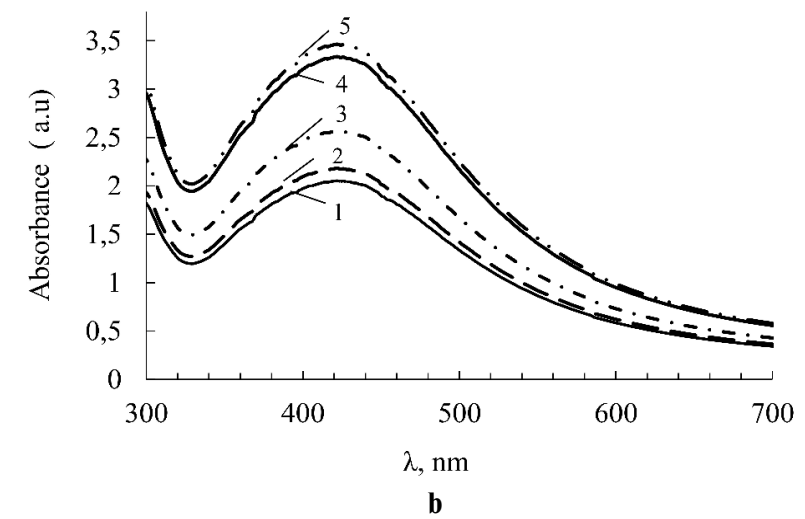

Fig. 1. Absorption spectra of silver colloidal solutions prepared by different methods and $\mathrm{Ag}^{+}$concentrations: (a) chemical synthesis using plasma-chemically prepared grape pomace water extract; and (b) plasma-chemical-assisted synthesis using grape pomace in the aqueous medium: $\mathrm{Ag}^{+}$concentration $(\mathrm{mmol} / \mathrm{L}): 1-0.25,2-0.5,3-1.0,4-3.0$ and $5-6.0$ 


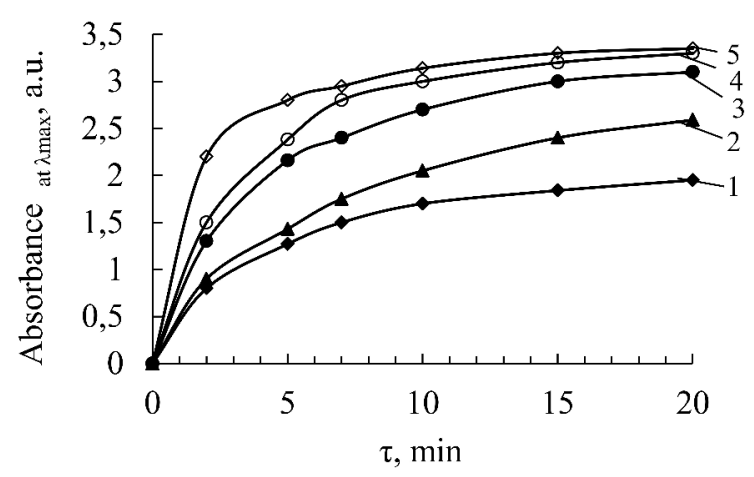

a

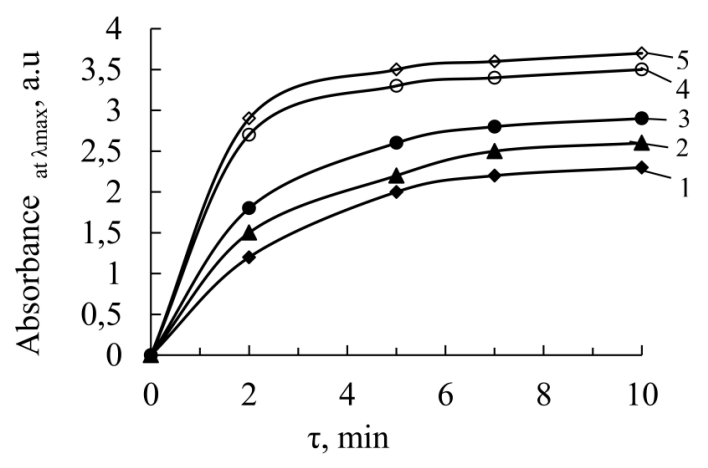

b

Fig. 2. Dependence of the absorbance (at $\lambda_{\max }$ ) of prepared colloidal solutions of AgNPs on the synthesis duration under different preparation methods and $\mathrm{Ag}^{+}$concentrations: (a) chemical synthesis using plasma-chemically obtained grape pomace water extract; and (b) plasma-chemical-assisted synthesis using grape pomace in the aqueous medium. $\mathrm{Ag}^{+}$concentration (mmol/L): $1-0.25,2-0.5,3-1.0,4-3.0$ and $5-6.0(\tau=10 \mathrm{~min})$

for the conversion of $\mathrm{Ag}^{+}$into nanoparticles decreases by two times $(5-7 \mathrm{~min})$.

The dynamic light scattering technique was used to determine the mean particle size and polydispersity index (Table). The particle size distribution was evaluated for different $\mathrm{Ag}^{+}$concentration by both methods. It was shown that silver nanoparticles with a narrow size distribution were formed. The obtained data indicate that the average diameter of the nanoparticles formed via both methods is equal to $20-33 \mathrm{~nm}$ and slightly grows with increasing initial $\mathrm{Ag}^{+}$concentration. The polydispersity index of AgNPs prepared by the plasma-chemical-assisted method was $0.18-0.23$, which indicates the stability of the nanoparticles.

\section{The particle size and polydispersity index of prepared silver nanoparticles}

\begin{tabular}{c|c|c|c|c}
\hline \multirow{2}{*}{$\begin{array}{c}\mathrm{A} \mathrm{AgNO}_{3}, \\
\mathrm{mmol} / \mathrm{L}\end{array}$} & $\begin{array}{c}\text { Average particle size, } \\
\mathrm{d}_{\mathrm{AgNPs}}, \mathrm{nm}\end{array}$ & \multicolumn{2}{c}{ Polydispersity index } \\
\cline { 2 - 5 } & Method I & Method II & Method I & Method II \\
\hline 0.25 & 27.0 & 20.0 & 0.25 & 0.18 \\
\hline 0.50 & 28.9 & 22.2 & 0.27 & 0.20 \\
\hline 1.00 & 30.0 & 24.3 & 0.31 & 0.21 \\
\hline 3.00 & 31.1 & 27.7 & 0.31 & 0.22 \\
\hline 6.00 & 33.0 & 29.1 & 0.58 & 0.23 \\
\hline
\end{tabular}

The SEM images of the prepared AgNPs are shown in Fig. 3,a,b. The observed morphology of the samples indicates that spherical nanoparticles are formed.

The microstructure of the synthesized AgNPs was investigated by XRD technique (Fig. 4). The AgNPs powder was obtained under the following conditions: $\tau=10 \mathrm{~min}$ and $\mathrm{C}\left(\mathrm{AgNO}_{3}\right)=6.0 \mathrm{mmol} / \mathrm{L}$.
The XRD peaks at $27.81^{0}, 32.16^{0}, 38.1^{0}, 46.1^{0}, 54.55^{0}$, $66.74^{\circ}$, and $76.84^{\circ}$ correspond to $210,122,111,200$, 142,220 , and 311 crystalline planes for cubic crystalline structure of metallic silver (JCPDS card number 04-0783), respectively. The intensity of the peaks reflects a high degree of crystallinity of the silver nanoparticles.

Various nitro-aromatic compounds are extensively used in textile, paper, pharmaceutical, cosmetic, leather, plastic and food industries. According to the report generated by the US environment protection Agency (EPA), 4-nitrophenol belongs to the most widespread and dangerous nitro-aromatic wastes and toxic chemicals [15]. Thus, the reduction reaction of 4-nitrophenol to 4-aminophenol (4-AP) is a very important issue.

To evaluate the catalytic performance, the synthesized AgNPs were used for the degradation of 4-nitrophenol, an anthropogenic pollutants that is harmful to the environment. Though the reduction of 4-NP to 4-AP by using aqueous $\mathrm{NaBH}_{4}$ solution is thermodynamically favorable ( $\mathrm{E}^{0}$ is equal to $0.76 \mathrm{~V}$ and $1.33 \mathrm{~V}$ vs. NHE for 4-NP/4-AP and $\mathrm{H}_{3} \mathrm{BO}_{3} / \mathrm{BH}_{4}$, respectively), the potential barrier due to a large potential difference between donor and acceptor molecules decreases the feasibility of this reaction. It is well-known that the metal AgNPs catalyze this reaction by facilitation of electron transfer from the donor, $\mathrm{BH}_{4}$, to the acceptor, 4-NP.

The data given in Fig. 5,a,b show that 4-NP reveals the absorbance peak at $\sim 317 \mathrm{~nm}$, which shifts to $400 \mathrm{~nm}$ in the presence of $\mathrm{NaBH}_{4}$ due to the formation of 4-nitrophenolate ion in the alkaline medium caused by $\mathrm{NaBH}_{4}$. The progress of the reaction was monitored by the UV-Vis absorption spectroscopy and confirmed visually by the disappearance of the yellow color of 4-NP. The 


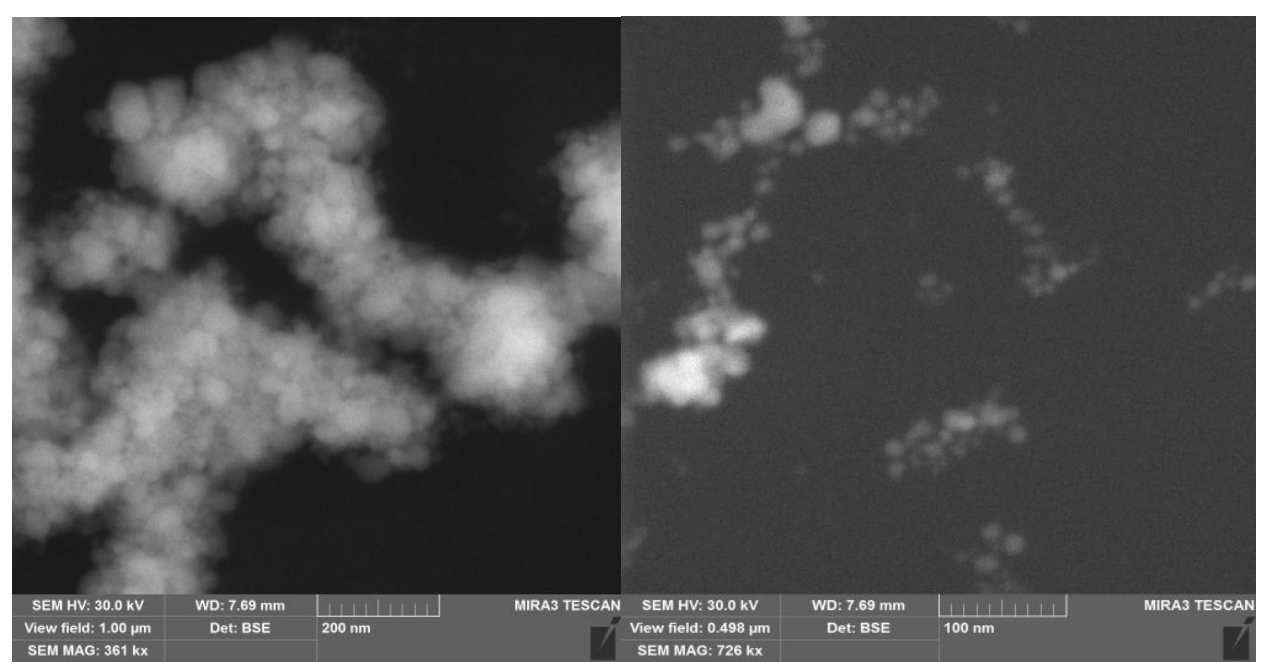

a

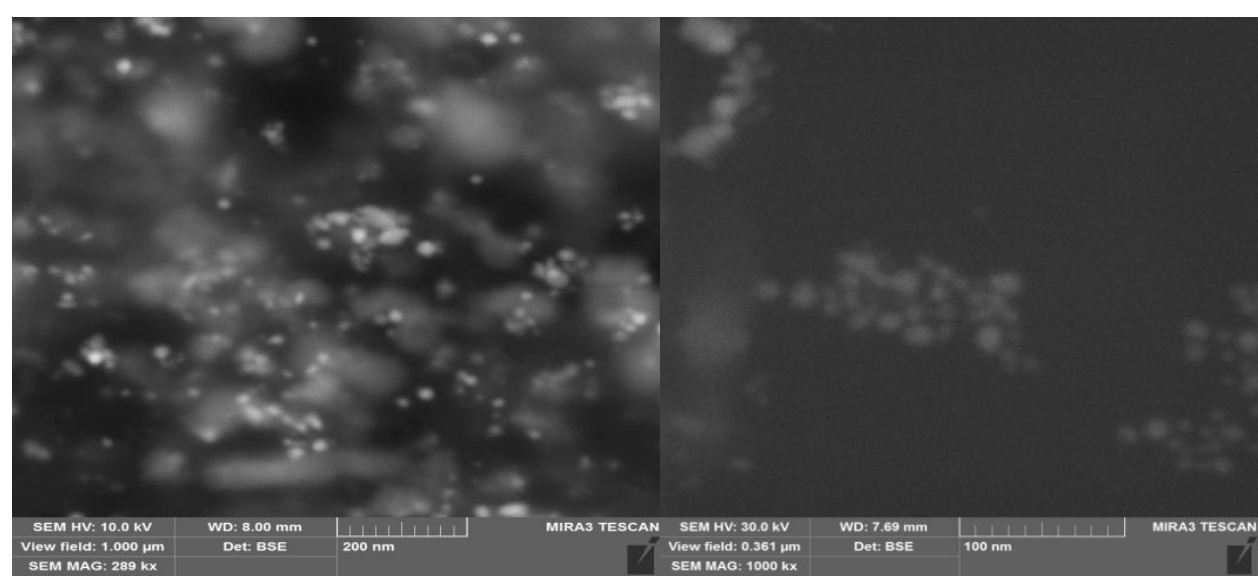

b

Fig. 3. SEM images of prepared silver nanoparticles: (a) chemical synthesis using plasma-chemically prepared grape pomace

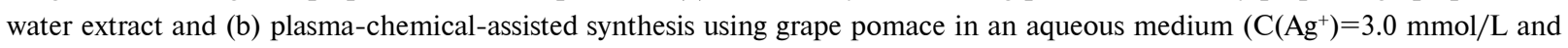
$\tau=10 \mathrm{~min})$

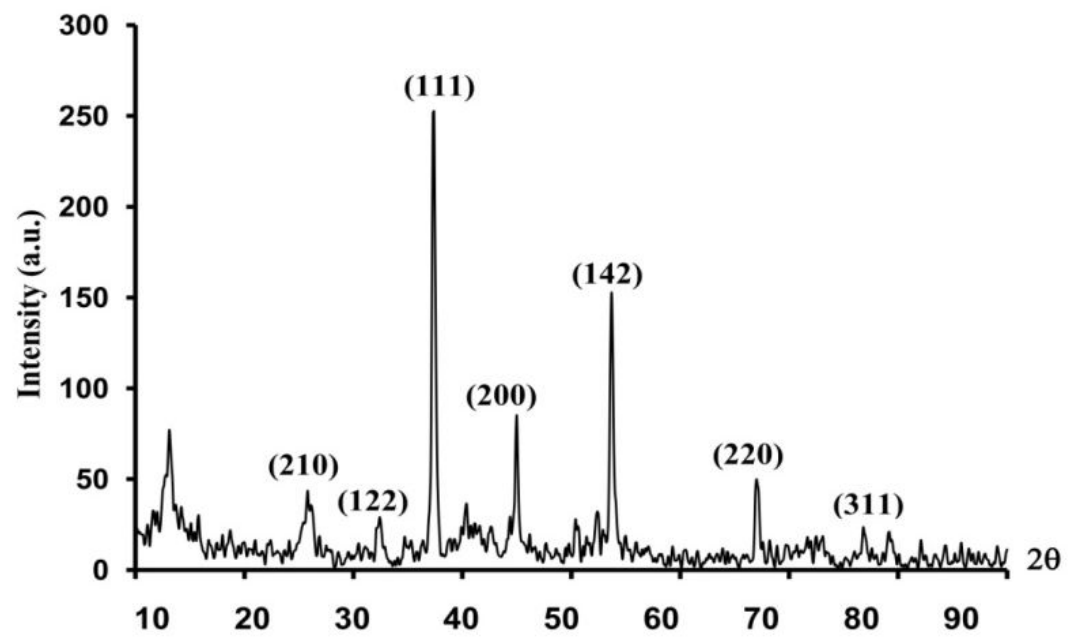

Fig. 4. X-ray diffraction pattern of silver nanoparticles (plasma-chemical-assisted synthesis using grape pomace in an aqueous medium $\left(\mathrm{C}\left(\mathrm{Ag}^{+}\right)=3.0 \mathrm{mmol} / \mathrm{L}\right.$ and $\left.\tau=10 \mathrm{~min}\right)$ 

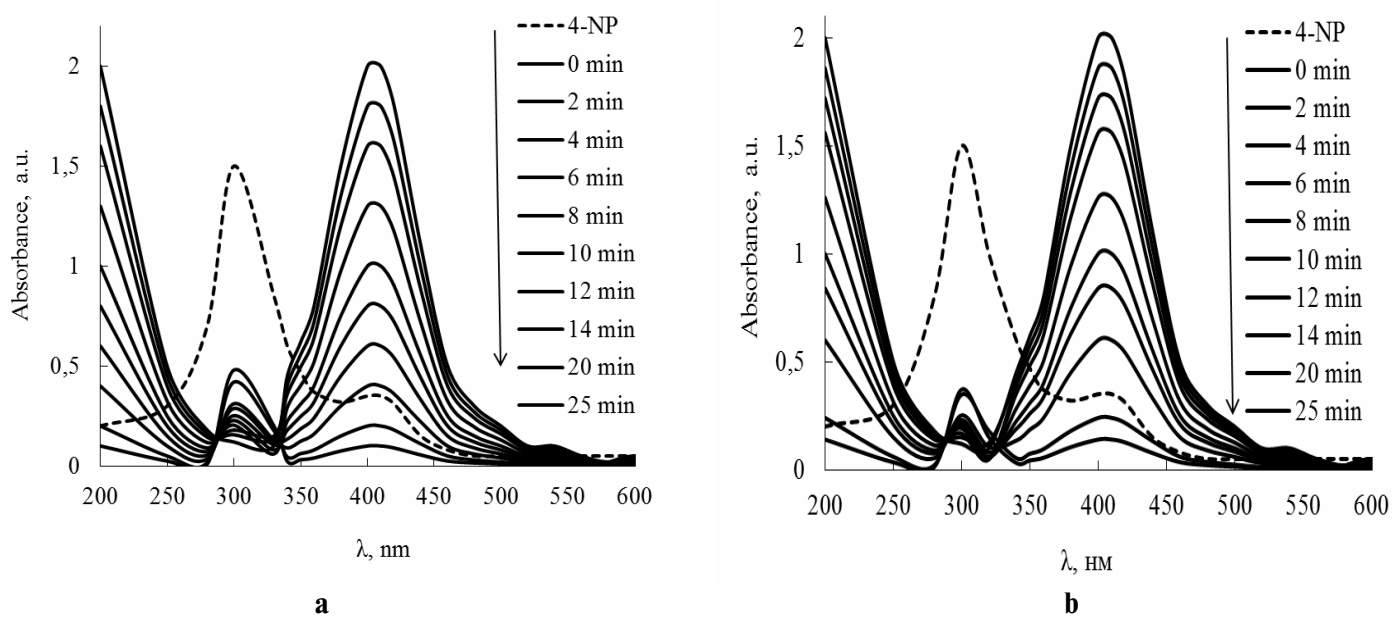

a

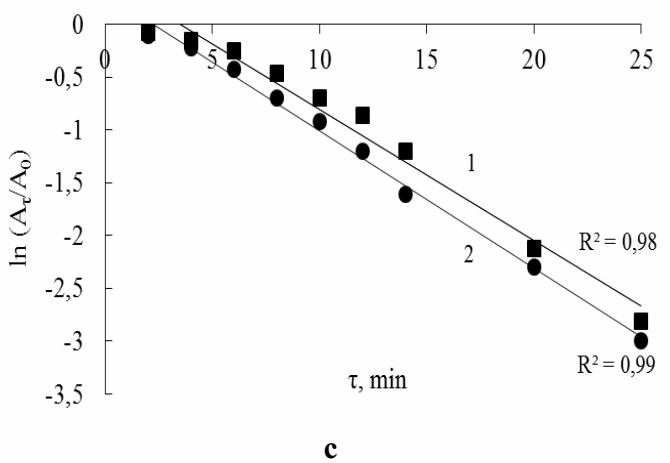

Fig. 5. Time-dependent UV-visible spectra for the catalytic reduction of 4-NP by $\mathrm{NaBH}_{4}$ in the presence of AgNPs obtained using two different methods: (a) chemical synthesis using plasma-chemically obtained grape pomace water extract; and (b) plasma-chemical-assisted synthesis using grape pomace in the aqueous medium.

(c) Plots of $\ln \left(\mathrm{A}_{t} / \mathrm{A}_{0}\right)$ vs. time for the reduction of $4-\mathrm{NP}$ by $\mathrm{NaBH}_{4}$ in the presence of $\mathrm{AgNPs}$

introduction of nanoparticles leads to the rapid decrease in the absorption peak intensity at $400 \mathrm{~nm}$, and, at the same time, to the concomitant appearance of a new peak at $298 \mathrm{~nm}$, which indicates the formation of the reduction product, 4-AP. The reaction is completed within $20-25 \mathrm{~min}$ in the presence of AgNPs.

The control of the above reaction was performed by taking water instead of the nanoparticle solution. The peak at $400 \mathrm{~nm}$ remained unchanged even after 3 days that confirmed the catalytic role of the nanoparticles for the above reduction reaction.

Since the concentration of $\mathrm{NaBH}_{4}$ significantly exceeds 4-NP, the reduction rate, probably, is independent of $\mathrm{NaBH}_{4}$ concentration. Therefore, the catalytic rate constant in this case can be evaluated by studying the pseudo-first-order kinetics with respect to 4-NP concentration. Figure 5, c shows that there is a good linear relation between $\ln \left(\mathrm{A}_{\mathrm{t}} / \mathrm{A}_{0}\right)$ and time after the induction time; the catalytic rate constants is $0.11-0.13 \mathrm{~min}^{-1}$.

\section{Conclusions}

The environmentally friendly technique was developed to produce metal nanoparticles using green synthesis methods. UV-visible absorption spectral characteristics of the silver nanoparticles prepared at different $\mathrm{Ag}^{+}$concentration and synthesis duration were determined. The UV-Vis spectrum of AgNPs exhibited a surface plasmon absorption at about 405$420 \mathrm{~nm}$, which originated from the formation of AgNPs. The prepared AgNPs were spherical with the average particle size of about $20-33 \mathrm{~nm}$. The crystal structure of the synthesized nanoparticles corresponded to the face-centered cube according to the data of powder XRD analysis. The catalytic performance of AgNPs was illustrated in the reaction of degradation of a pollutant, 4-nitrophenol. Thus, our study offers an effective and eco-friendly approach to the purification of the environment from organic pollutants.

\section{Acknowledgments}

This work was supported by a grant of the Ministry of Education and Science of Ukraine No. 1439 (22.12.2018), 2019-2021. 


\section{REFERENCES}

1. Recent advances in green synthesis of silver nanoparticles and their applications: about future directions. A review / Abdelghany T.M., Al-Rajhi A.M.H., Al Abboud M.A., Alawlaqi M.M., Ganash Magdah A., Helmy E.A.M., Mabrouk A.S. // BioNanoScience. - 2017 - Vol.8. - No. 1 - P.5-16.

2. New insights on the green synthesis of metallic nanoparticles using plant and waste biomaterials: current knowledge, their agricultural and environmental applications / Saratale R.G., Saratale G.D., Shin H.S., Jacob J.M., Pugazhendhi A., Bhaisare M., Kumar G. // Environ. Sci. Pollut. Res. -2018. - Vol.25. - No. 11. - P.10164-10183.

3. Usubiaga A., Butnar I., Schepelmann P. Wasting food, wasting resources: potential environmental savings through food waste reductions // J. Ind. Ecol. - 2018. - Vol.22. - No. 3. P.574-584.

4. Fruit waste (peel) as bio-reductant to synthesize silver nanoparticles with antimicrobial, antioxidant and cytotoxic activities / Annu, Ahmed S., Kaur G., Sharma P., Singh S., Ikram S. // J. Appl. Biomed. - 2018. - Vol.16. - No. 3. P.221-231.

5. Extraction and consecutive purification of anthocyanins from grape pomace using ionic liquid solutions / Lima A.S., Soares C.M.F., Paltram R., Halbwirth H., Bica K. // Fluid Phase Equilib. - 2017. - Vol.451. - P.68-78.

6. Microwave-assisted extraction of phenolic compounds from dried waste grape skins / Pedroza M.A., Amendola D., Maggi L., Zalacain A., De Faveri D.M., Spigno G. // Int. J. Food Eng. - 2015. - Vol.11. - No. 3. - P.359-370.

7. Microwave pretreatment to improve extraction efficiency and polyphenol extract richness from grape pomace. Effect on antioxidant bioactivity / Alvarez A., Poejo J., Matias A.A., Duarte C.M.M., Cocero M.J., Mato R.B. // Food Bioprod. Process. -2017. - Vol.106. - P.162-170.

8 Fatimah I., Indriani N. Silver nanoparticles synthesized using lantana camara flower extract by reflux, microwave and ultrasound methods // Chem. J. Moldova. - 2018 - Vol.13. No. 1. - P.95-102.

9. Pulsed electric field treatment of citrus fruits: Improvement of juice and polyphenols extraction / El Kantar S., Boussetta N., Lebovka N., Foucart F., Rajha H.N., Maroun R.G., Louka N., Vorobiev E. // Innovative Food Sci. Emerging Technol. - 2018. - Vol.46. - P.153-161.

10. Plasma-chemical formation of silver nanodisperssion in water solutions / Skiba M.I., Pivovarov A.A., Makarova A.K., Pasenko A.A., Khlopytskyi A.O., Vorobyova V.I. // East.-Eur. J. Enterprise Technol. - 2017 - Vol.6. - P.59-65.

11. Plasma-chemical synthesis of silver nanoparticles in the presence of citrate / Skiba M., Pivovarov A., Makarova A., Vorobyova V. // Chem. J. Moldova. - 2018. - Vol.13. - No. 1. - P. 7-14.
12. Preparation of silver nanoparticles by contact nonequilibrium low-temperature plasma in the presence of sodium alginate / Pivovarov O.A., Skiba M.I., Makarova A.K., Vorobyova V.I., Pasenko A.A. // Voprosy Khimii i Khimicheskoi Tekhnologii. 2017. - No. 6. - P.82-88.

13. Plasma-chemical formation of silver nanoparticles: the silver ions concentration effect on the particle size and their antimicrobial properties / Skiba M., Pivovarov A., Vorobyova V., Derkach T.M., Kurmakova I. // J. Chem. Technol. Metall. 2019. - Vol.54. - No. 2. - P.311-318.

14. Degradation of anthropogenic pollutant and organic dyes by biosynthesized silver nano-catalyst from Cicer arietinum leaves / Arya G., Sharma N., Ahmed J., Gupta N., Kumar A., Chandra R., Nimesh S. // J. Photochem. Photobiol. B. - 2017. - Vol.174. - P.90-96.

15. Recent advances in the nanocatalyst-assisted $\mathrm{NaBH}_{4}$ reduction of nitroaromatics in water / Zhang K., Suh J.M., Choi J.-W., Jang H.W., Shokouhimehr M., Varma R.S. // ACS Omega. - 2019 - Vol.4. - No. 1. - P. 483-495.

Received 22.04.2019

\section{ПЛАЗМОХІМІЧНИЙ СИНТЕЗ НАНОЧАСТИНОК СРІБЛА З ВИКОРИСТАННЯМ ВІДХОДІВ ПЕРЕРОБЛЕННЯ ВИНОГРАДУ}

\section{М.І. Скиба, В.І. Воробйова, О.А. Півоваров, К.О. Сорочкіна, A.С. Шакун}

Дисперсії наночастинок срібла (АgНЧ) були одержсані двома методами: хімічним відновленням з використанням попередньо плазмохімічно одержсаного водного екстракту відходів перероблення винограду як відновлюючого і стабілізуючого агента та одностадійним плазмохімічним синтезом з використанням відходів перероблення винограду у водному середовищі. УФспектри АgНЧ показали поглинання в діапазоні 405-420 нм, що обумовлено утворенням АgНЧ. Досліджено спектральні характеристики УФ-видимого поглинання наночастинок срібла, одержсаних при різних концентраціях $\mathrm{Ag}^{+}$i тривалості синтезу. Результати показали, що синтез обома методами забезпечує формування наночастинок срібла при досліджуваних концентраціях $\mathrm{Ag}^{+}(0,25-6,0$ ммоль/л) протягом 5-10 хв. Динамічне світлорозсіювання і сканувальну електронну мікроскопію було використано для вимірювання гідродинамічних розмірів $i$ морфології наночастинок срібла в суспензіях. Встановлено, що одержані $\mathrm{Ag} \mathrm{HЧ} \mathrm{є} \mathrm{сферичними} \mathrm{із} \mathrm{середнім} \mathrm{розміром} \mathrm{частинок}$ близько 20-33 нм. Результати рентгеноструктурного аналізу порошку показують, що наночастинки Ag мають гранецентровану кубічну кристалічну структуру. Каталітичні властивості наночастинок були досліджені шляхом відновлення 4-нітрофенолу до 4-амінофенолу в присутності боргідріду натрію.

Ключові слова: наночастинки срібла, низькотемпературна нерівноважна плазма, вичавки винограду, каталітичне руйнування, нітрофенол. 


\section{PLASMA-CHEMICAL-ASSISTED SYNTHESIS OF SILVER NANOPARTICLES USING GRAPE POMACE WASTE}

\author{
M.I. Skiba ${ }^{a,}$, V.I. Vorobyova ${ }^{b}$, O.A. Pivovarov ${ }^{a}$, \\ K.O. Sorochkina ${ }^{a}$, A.S. Shakun ${ }^{b}$
}

a Ukrainian State University of Chemical Technology, Dnipro, Ukraine

b National Technical University of Ukraine «Igor Sikorsky Kyiv Polytechnic Institute», Kyiv, Ukraine

*e-mail: margaritaskiba88@gmail.com

Dispersions of silver nanoparticles (AgNPS) were prepared by two methods: a chemical reduction using plasma-chemically obtained water extract of grape pomace as a reducing and stabilizing agent and one-pot plasma-chemical-assisted synthesis using a grape pomace in an aqueous medium. The UV-vis spectrum of AgNPs exhibited a surface plasmon absorption at about 405-420 $\mathrm{nm}$, which originated from the formation of AgNPs. The UV-visible absorption spectral characteristics of silver nanoparticles prepared under different $\mathrm{Ag}^{+}$ concentrations and durations of synthesis were studied. The results demonstrated that the synthesis via both methods provides the formation of AgNPs at the investigated concentrations of $\mathrm{Ag}^{+}(0.25-$ $6.0 \mathrm{mmol} / \mathrm{L}$ ) during 5-10 min. Dynamic light scattering and scanning electron microscopy were employed to measure the hydrodynamic size and morphology of silver nanoparticles in suspensions. The prepared AgNPs were spherical with an average particle size of about $20-33 \mathrm{~nm}$. The results of powder X-ray diffraction method revealed that Ag nanoparticles had a face-centered cubic crystal structure. The catalytic performance of the AgNPs were ascertained in the reduction of 4-nitrophenol to 4-aminophenol in the presence of sodium borohydride.

Keywords: silver nanoparticle; low-temperature none-quilibrium plasma; grape pomace; catalytic degradation; nitrophenol.

\section{REFERENCES}

1. Abdelghany T.M., Al-Rajhi A.M.H., Al Abboud M.A., Alawlaqi M.M., Ganash Magdah A., Helmy E.A.M., Mabrouk A.S. Recent advances in green synthesis of silver nanoparticles and their applications: about future directions. A review. BioNanoScience, 2017, vol. 8, pp. 5-16.

2. Saratale R.G., Saratale G.D., Shin H.S., Jacob J.M., Pugazhendhi A., Bhaisare M., Kumar G. New insights on the green synthesis of metallic nanoparticles using plant and waste biomaterials: current knowledge, their agricultural and environmental applications. Environmental Science and Pollution Research, 2018, vol. 25, pp. 10164-10183.

3. Usubiaga A., Butnar I., Schepelmann P. Wasting food, wasting resources: potential environmental savings through food waste reductions. Journal of Industrial Ecology, 2018, vol. 22, pp. 574-584.

4. Annu, Ahmed S., Kaur G., Sharma P., Singh S., Ikram S. Fruit waste (peel) as bio-reductant to synthesize silver nanoparticles with antimicrobial, antioxidant and cytotoxic activities. Journal of Applied Biomedicine, 2018, vol. 16, pp. 221231
5. Lima A.S., Soares C.M.F., Paltram R., Halbwirth H., Bica K. Extraction and consecutive purification of anthocyanins from grape pomace using ionic liquid solutions. Fluid Phase Equilibria, 2017, vol. 451, pp. 68-78.

6. Pedroza M.A., Amendola D., Maggi L., Zalacain A., De Faveri D.M., Spigno G. Microwave-assisted extraction of phenolic compounds from dried waste grape skins. International Journal of Food Engineering, 2015, vol. 11, pp. 359-370.

7. Alvarez A., Poejo J., Matias A.A., Duarte C.M.M., Cocero M.J., Mato R.B. Microwave pretreatment to improve extraction efficiency and polyphenol extract richness from grape pomace. Effect on antioxidant bioactivity. Food and Bioproducts Processing, 2017, vol. 106, pp. 162-170.

8. Fatimah I., Indriani N. Silver nanoparticles synthesized using lantana camara flower extract by reflux, microwave and ultrasound methods. Chemistry Journal of Moldova, 2018, vol. 13, pp. 95-102.

9. El Kantar S., Boussetta N., Lebovka N., Foucart F., Rajha H.N., Maroun R.G. Louka N., Vorobiev E. Pulsed electric field treatment of citrus fruits: improvement of juice and polyphenols extraction. Innovative Food Science \& Emerging Technologies, 2018, vol. 46, pp. 153-161.

10. Skiba M.I., Pivovarov A.A., Makarova A.K., Pasenko A.A., Khlopytskyi A.O., Vorobyova V.I. Plasma-chemical formation of silver nanodisperssion in water solutions. Eastern-European Journal of Enterprise Technologies, 2017, vol. 6, pp. 59-65.

11. Skiba M., Pivovarov A., Makarova A., Vorobyova V. Plasma-chemical synthesis of silver nanoparticles in the presence of citrate. Chemistry Journal of Moldova, 2018, vol. 13, pp. 7-14.

12. Pivovarov O.A., Skiba M.I., Makarova A.K., Vorobyova V.I., Pasenko O.O. Preparation of silver nanoparticles by contact nonequilibrium low-temperature plasma in the presence of sodium alginate. Voprosy Khimii i Khimicheskoi Tekhnologii, 2017, no. 6, pp. 82-88.

13. Skiba M., Pivovarov A., Vorobyova V., Derkach T., Kurmakova I. Plasma-chemical formation of silver nanoparticles: the silver ions concentration effect on the particle size and their antimicrobial properties. Journal of Chemical Technology and Metallurgy, 2019, vol. 54, pp. 311-318.

14. Arya G., Sharma N., Ahmed J., Gupta N., Kumar A., Chandra R., Nimesh S. Degradation of anthropogenic pollutant and organic dyes by biosynthesized silver nano-catalyst from Cicer arietinum leaves. Journal of Photochemistry and Photobiology, B: Biology, 2017, vol. 174, pp. 90-96.

15. Zhang K., Suh J.M., Choi J.W., Jang H.W., Shokouhimehr M., Varma R.S. Recent advances in the nanocatalyst-assisted $\mathrm{NaBH}_{4}$ reduction of nitroaromatics in water. ACS Omega, 2019, vol. 4, pp. 483-495. 